\title{
PEMBERIAN SCAFFOLDING TERHADAP MISKONSEPSI SISWA DALAM MENYELESAIKAN SOAL MATERI HIMPUNAN
}

\author{
Nuril Intan \\ Pendidikan Matematika, Fakultas Matematika dan Ilmu Pengetahuan Alam, Universitas Negeri Surabaya \\ e-mail: nurilintan16030174073@ mhs.unesa.ac.id \\ Masriyah \\ Pendidikan Matematika, Fakultas Matematika dan Ilmu Pengetahuan Alam, Universitas Negeri Surabaya \\ e-mail: masriyah@unesa.ac.id
}

\begin{abstract}
Abstrak
Penelitian ini bertujuan untuk mendeskripsikan miskonsepsi siswa dalam menyelesaikan soal materi himpunan sebelum dan sesudah pemberian scaffolding, bentuk scaffolding yang diberikan, dan dampak pemberian scaffoldingnya. Penelitian ini merupakan penelitian kualitatif, yang dilakukan di SMPN 32 Surabaya dengan memilih 2 orang subjek yang mengalami miskonsepsi dari salah satu kelas yang berjumlah 35 siswa. Instrumen yang digunakan adalah tes diagnostik I dan II yang dilengkapi CRI, pedoman wawancara dan pedoman scaffolding. Materi yang dipilih pada penelitian ini adalah himpunan. Miskonsepsi dalam penelitan ini dianalisis berdasarkan jenisnya, yaitu miskonsepsi klasifikasional, korelasional dan teoritikal. Scaffolding dalam penelitian ini adalah explaining reviewing, and restructuring yang terdiri atas (1) looking, touching and verbalising (2) Pompting and probing (3) interpreting student's actions and talk, (4) paraldell modelling dan (5) students explaining and justifying, restructuring yang terdiri atas (1) identify meaningfull context (2) simplifying the problem (3) re-pharasing studdent's talk (4) negotiating meaning, developing conceptual thinking yang terdiri atas developing representational tools dan making connection. Berdasarkan penelitian yang dilakukan oleh peneliti, terdapat 16,53\% miskonsepsi klasifikasional, 49,59\% miskonsepsi korelasional ada dan 49,59\% miskonsepsi teoritikal. Setelah diberikan scaffolding, miskonsepsi siswa dalam menyelesaikan soal materi himpunan berkurang bahkan tidak lagi mengalami miskonsepsi. Oleh karena itu, scaffolding merupakan salah satu alternatif untuk merespon miskonsepsi yang dialami oleh siswa dalam menyelesaikan soal materi himpunan.
\end{abstract}

Kata Kunci : Miskonsepsi, scaffolding, himpunan.

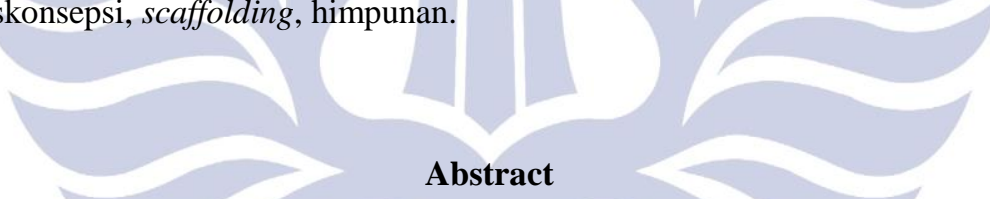

This study aims to describe the students' misconceptions in completing sets of material problems before and after scaffolding, the form of scaffolding provided, and the impact of giving scaffolding. This research is a qualitative study, which was conducted in Junior High School of 32 Surabaya by selecting 2 subjects who experienced misconceptions from one class of 35 students. The instrument used was a diagnostic test I and II equipped with CRI, interview guidelines and scaffolding guidelines. The material chosen in this study is the set. Misconceptions in this research are analyzed based on its type, namely classification, correlation and theoretical misconceptions. Scaffolding in this research is explaining reviewing, and restructuring which consists of (1) looking, touching and verbalising (2) Pompting and probing (3) interpreting student's actions and talk, (4) parallelling modeling and (5) students explaining and justifying, restructuring which consists of (1) identifying meaningful context (2) simplifying the problem (3) re-pharasing studdent's talk (4) negotiating meaning, developing conceptual thinking consisting of developing representational tools and making connections. Based on research conducted by researchers, there are $16.53 \%$ of classification misconceptions, $49.59 \%$ of correlation misconceptions exist and $49.59 \%$ of theoretical misconceptions. After being given scaffolding, students' misconceptions in solving the set material matter diminished and no longer even experienced misconceptions. Therefore, scaffolding is an alternative to responding to misconceptions experienced by students in solving set material problems.

Keywords: Misconception, scaffolding, set. 


\section{PENDAHULUAN}

Pembelajaran matematika merupakan proses yang dirancang dengan tujuan untuk menciptakan suasana lingkungan yang memungkinkan siswa melaksanakan kegiatan belajar matematika (Masriyah, dkk., 2007). Meskipun kegiatan belajar matematika selalu dilakukan siswa di sekolah bahkan di lingkungan sehari-hari, sering sekali siswa tidak faham bahkan salah dalam memahami konsepnya.

Pemahaman konsep matematika sangat mempengaruhi siswa dalam mengerjakan soal-soal matematika. Karena, pemahaman konsep merupakan dasar yang harus dicapai oleh siswa agar lebih mudah melanjutkan ke tingkat pemahaman selanjutnya. Ada tiga kategori pemahaman konsep yaitu tidak faham konsep, miskonsepsi dan faham konsep (Abraham, dkk., 1992). Salah satu sumber kesalahan matematika adalah miskonsepsi. Karena, miskonsepsi dapat menyebabkan penghambatan proses pengetahuan baru, sehingga siswa mengalami kesalahan saat pembelajaran (Herutomo \& Saputro, 2014). Miskonsepsi adalah pengertian yang tidak akurat akan konsep, klasifikasi contoh- contoh yang salah, penggunaan konsep yang berbeda, dan hubungan hirarkis konsepkonsep yang tidak benar (Suparno, 2013).

Berbagai jenis miskonsepsi telah banyak dikemukakan oleh para ahli (Ashlock, 2006). Moh. Amien (dalam Salirawati, 2010:13), mendefinisikan beberapa jenis miskonsepsi siswa sesuai bentuk dan karakteristiknya yaitu : (1) Miskonsepsi klasifikasional, yaitu bentuk miskonsepsi yang didasarkan atas kesalahan klasifikasi fakta-fakta ke dalam bagan-bangan yang terorganisir. (2) Miskonsepsi korelasional, yaitu bentuk miskonsepsi yang didasarkan atas kesalahan mengenai kejadian-kejadian khusus yang saling berhubungan, atau observasi-observasi yang terdiri atas dugaan-dugaan terutama bentuk formulasi prinsip-prinsip umum. (3) Miskonsepsi teoritikal, yaitu bentuk miskonsepsi yang didasarkan atas kesalahan dalam mempelajari fakta-fakta atau kejadiankejadian dalam sistem yang terorganisir.

Materi himpunan sering kali menimbulkan miskonsepsi pada siswa (Nurtasari, dkk., 2012). Berdasarkan Permendikbud No. 37 tahun 2018, Materi pokok himpunan yang diajarkan di tingkat SMP meliputi pengertian himpunan, himpunan bagian, himpunan semesta, himpunan kosong, komplemen himpunan, dan menyelesaikan operasi pada himpunan menggunakan masalah kontekstual. Di antara materi himpunan tersebut, miskonsepsi yang sering terjadi adalah pada sub bahasan pengertian himpunan, himpunan bagian, operasi pada himpunan dan operasi pada himpunan menggunakan masalah kontekstual (Nurtasari, dkk., 2012).
Ormrod (2009), menyatakan bahwa miskonsepsi dapat menghambat pembelajaran. Siswa akan sulit untuk memahami konsep selanjutnya karena siswa telah mengalami miskonsepsi pada konsep awal. Materi himpunan merupakan materi prasyarat untuk materi berikutnya, seperti materi relasi dan fungsi pada kelas VIII maupun materi fungsi di SMA. Dapat disimpulkan bahwa, ketika siswa mengalami miskonsepsi pada materi himpunan, maka siswa juga sulit bahkan mengalami miskonsepsi lagi untuk materi berikutnya seperti relasi dan fungsi. Untuk itu, identifikasi miskonsepsi siswa perlu untuk dilakukan.

Identifikasi miskonsepsi pada siswa perlu dilakukan lebih awal untuk mengetahui bagian mana siswa sering mengalami miskonsepsi pada materi himpunan dan penyebab terjadinya miskonsepsi. Sudjana (2011) memaparkan bahwa tes diagnostik merupakan tes yang bertujuan untuk melihat kelemahan dan kesulitan siswa serta faktor penyebab mengapa kesulitan dan kelemahan itu terjadi. Setelah diberi tes, guru akan mengetahui di mana letak kesalahan maupun ketidakfaman siswa tentang materi himpunan. Tidak semua kesalahan adalah miskonsepsi. Salah satu metode yang bisa digunakan untuk mendeteksi miskonsepsi siswa adalah CRI (Certainty of Respon Indeks). CRI adalah tingkat keyakinan siswa dalam menjawab soal (Tayubi, 2005:5). Hasan, dkk. (1999) mengemukakan bahwa CRI menggunakan rubrik dengan penskoran (0-5) dengan klasifikasi 0 untuk totally guested answer, 1 untuk almost guest, 2 untuk not sure, 3 untuk sure, 4 untuk almost certain, dan 5 untuk certain. Berikut merupakan tabel CRI skala 6 dan kriterianya.

Tabel 1. CRI skala 6 dan kriterianya

\begin{tabular}{|c|c|c|}
\hline Skala & Kriteria & Keterangan \\
\hline $\mathrm{e}^{0}$ & $\begin{array}{l}\text { totally } \\
\text { guested } \\
\text { answer }\end{array}$ & $\begin{array}{l}\text { If you dont know about the } \\
\text { concept }\end{array}$ \\
\hline 1 & $\begin{array}{l}\text { almost } \\
\text { guest }\end{array}$ & $\begin{array}{l}\text { If you know the concept but you } \\
\text { have } \\
\text { difficulties to solve it }\end{array}$ \\
\hline 2 & not sure & $\begin{array}{l}\text { If you know the concept but you } \\
\text { not sure with your answer }\end{array}$ \\
\hline 3 & Sure & If you know about the concept \\
\hline 4 & $\begin{array}{l}\text { almost } \\
\text { certain }\end{array}$ & $\begin{array}{l}\text { If you really know about the } \\
\text { concept }\end{array}$ \\
\hline 5 & Certain & If you answer definitely right \\
\hline
\end{tabular}

Sumber : Hasan, dkk. (1999)

Berikut ini diberikan Tabel 2 yaitu tabel ketentuan CRI untuk memedakan antara tahu konsep, miskonsepsi dan tidak tahu konsep oleh Hasan, dkk. (1999). 
Tabel 2. Ketentuan CRI untuk membedakan tahu konsep, miskonsepsi dan tidak tahu konsep

\begin{tabular}{|c|c|c|}
\hline $\begin{array}{l}\text { Kriteria } \\
\text { Jawaban }\end{array}$ & $\begin{array}{c}\text { CRI rendah, } \\
(<2,5)\end{array}$ & CRI tinggi $(>2,5)$ \\
\hline $\begin{array}{c}\text { Jawaban } \\
\text { benar }\end{array}$ & $\begin{array}{c}\text { Tidak tahu konsep } \\
\text { (Lucky guess) }\end{array}$ & $\begin{array}{l}\text { Menguasai } \\
\text { konsep } \\
\\
\mathrm{n} \\
\text { baik. }\end{array}$ \\
\hline $\begin{array}{c}\text { Jawaban } \\
\text { salah }\end{array}$ & Tidak tahu konsep & $\begin{array}{c}\text { Kemungkinan } \\
\text { terjadi } \\
\text { miskonsepsi. }\end{array}$ \\
\hline
\end{tabular}

Sumber : Hasan, dkk. (1999)

Setelah mengetahui miskonsepsi yang dialami oleh siswa, guru dapat memberikan bantuan yang efektif agar siswa tidak mengalami miskonsepsi yang berkelanjutan. Pemberian bantuan tersebut dapat berupa scaffolding. Scaffolding pertama kali digagas oleh salah satu ilmuan yang bernama Vygotsky. Menurut Sudrajad (2013), scaffolding dapat diartikan sebagai suatu teknik pemberian bantuan belajar secara terstruktur, yang dilakukukan pada tahap awal untuk mendorong siswa agar dapat bekerja secara mandiri. Saat siswa dipandang telah bisa menyelesaikan tugasnya sendiri maka pada saat itu guru mulai dengan proses pemberhentian pemberian bantuan agar siswa dapat bekerja dengan mandiri (Sutiarso, 2009). (Anghileri, 2006) mengkategorikan scaffolding menjadi tiga level, sebagai berikut. Level 1: environmental Provision, Level 2: explaining reviewing, and restructuring. Untuk reviewing sendiri terdiri atas (a) looking, touching and verbalising (b) Pompting and probing (c) interpreting student's actions and talk, (d) paraldell modelling dan (e) students explaining and justifying. Untuk restructuring terdiri atas (a) identify meaningfull context (b) simplifying the problem (c) repharasing studdent's talk (d) negotiating meaning. Level 3: developing conceptual thinking yang terdiri atas developing representational tools dan making connection.

Beberapa penelitian yang relevan sudah pernah dilakukan di antaranya penelitian yang dilakukan oleh Nurtasari, dkk. (2012) yang berjudul "Miskonsepsi Siswa pada Materi Himpunan di Kelas VII SMP Santa Monika Kubu Raya". Kemudian Damayanti (2016) yang berjudul “ Pembelajaran Berbasis Scaffolding Untuk mengurangi Miskonsepsi Aljabar Mahasiswa" dan Penelitian yang dilakukan oleh Ummah (2016) yang berjudul " Pemberian Scaffolding Berdasarkan Kesalahan Siswa dalam Menyelesaikan Soal yang Berkaitan Dengan Persegi dan Persegipanjang Ditinjau Dari Kemampuan Matematika". Beberapa penelitian yang relevan tersebut belum ada yang membahas tentang pemberian scaffolding terhadap miskonsepsi siswa dalam menyelesaikan soal materi himpunan. berdasarkan ulasan di atas, peneliti tertarik untuk mengetahui lebih rinci tentang deskripsi miskonsepsi siswa dalam menyelesaikan soal materi himpunan sebelum dan sesudah pemberian scaffolding, bentuk scaffolding yang diberikan, dan dampak pemberian scaffoldingnya.

\section{METODE}

Jenis penelitian ini merupakan penelitian kualitatif. Penelitian ini dilakukan di SMPN 32 Surabaya dengan memilih subjek 2 orang yang mengalami miskonsepsi dari satu kelas yang berjumlah 35 siswa. Instrumen dalam penelitian ini adalah tes diagnostik pertama yang dilengkapi CRI, pedoman wawancara, pedoman scaffolding dan tes diagnostik kedua yang dilengkapi CRI.

Tes pertama memuat 4 soal dengan jumlah 10 sub soal dengan spesifikasi butir soal nomor 1 memuat 4 pernyataan, siswa diminta untuk menentukan mana yang merupakan himpunan dan mana yang bukan merupakan himpunan, butir soal nomor 2 tentang himpunan bagian, butir soal nomor 3 tentang operasi pada himpunan yaitu sub soal 3a menentukan selisih dua himpunan, sub soal $3 \mathrm{~b}$ menentukan komplemen dari suatu himpunan jika diketahui semestanya, sub soal 3c menentukan gabungan dua himpunan, sub soal $3 \mathrm{~d}$ menentukan irisan dua himpunan dan untuk soal nomor 4 menyelesaikan operasi pada himpunan menggunakan masalah kontekstual.

Hasil tes pertama ini dianalisis untuk mengetahui miskonsepsi yang dialami oleh setiap siswa berdasarkan jenis miskonsepsi yang didefinisikan oleh Amien (dalam Salirawati, 2010:13) dengan memperhatikan indikator setiap jenis miskonsepsi dan bantuan CRI yang dikemukakan oleh Hasan, dkk. (1999) untuk setiap sub soalnya.

Selanjutnya, dua siswa dipilih untuk dijadikan subjek penelitian. Pemilihan subjek penelitian ini didasarkan pada siswa yang mengalami miskonsepsi terbanyak dengan jenis miskonsepsi yang beragam serta konsultasi peneliti dengan guru mitra apakah calon subjek dapat dijadikan subjek penelitian dengan mempertimbangkan kemampuan komunikasi calon subjek penelitian atau tidak.

Setelah memperoleh subjek, peneliti melakukan wawancara terhadap masing-masing subjek. Tujuan dilakukan wawancara adalah untuk menggali lebih dalam mengenai jenis miskonsepsi yang dialami oleh subjek dan bentuk scaffoldingnya. Setelah dilakukan wawancara, scaffolding diberikan secara one to one kepada masingmasing subjek. One to one scaffolding merupakan scaffolding yang diberikan kepada masing-masing subjek penelitian berdasarkan jenis miskonsepsi setiap subjek yang mengacu pada teori scaffolding yang dikemukakan oleh Anghileri (2006). Alasan peneliti memilih one to one scaffolding agar scaffolding yang diberikan untuk setiap subjek lebih terarah berdasarkan miskonsepsi yang 
dialami siswa dan pengembangannya disesuaikan dengan respon setiap subjek.

Setelah memberikan one to one scaffolding, peneliti memberikan tes kedua untuk mengetahui miskonsepsi siswa dalam menyelesaikan soal materi himpunan setelah diberi perlakuan scaffolding untuk bahan pendeskripsian tentang dampak pemberian scaffolding terhadap miskonsepsi siswa dalam menyelesaikan soal materi himpunan.

Soal tes kedua ini terdiri atas 4 soal dengan jumlah 10 sub soal (soal setara dengan soal tes pertama). Instrumen yang digunakan dalam penelitian ini dibuat oleh peneliti dan dikonsultasikan kepada dosen pembimbing sampai dinyatakan siap untuk digunakan.

\section{HASIL DAN PEMBAHASAN}

\section{Tes Pertama}

Dari 35 siswa yang mengikuti tes pertama, 35 siswa tersebut mengalami miskonsepsi dengan jenis dan banyaknya miskonsepsi yang beragam. Dari 10 pertanyaan, terdapat 20 miskonsepsi klasifikasional, 60 miskonsepsi korelasional dan 41 miskonsepsi teoritikal. Berikut merupakan tabel banyaknya miskonsepsi yang dialami oleh siswa.

Tabel 3. Banyaknya miskonsepsi yang dialami oleh siswa

\begin{tabular}{|c|c|c|c|c|c|}
\hline \multirow[t]{2}{*}{ No. } & \multirow[t]{2}{*}{ Konsep } & \multicolumn{4}{|c|}{$\begin{array}{c}\text { banyaknya miskonsepsi yang } \\
\text { dialami oleh siswa }\end{array}$} \\
\hline & & M1 & M2 & M3 & Jml \\
\hline $1 \mathrm{a}$ & $\begin{array}{l}\text { Menentukan mana yang } \\
\text { merupakan himpunan } \\
\text { dan mana yang bukan } \\
\text { merupakan himpunan }\end{array}$ & 6 & 0 & 3 & 9 \\
\hline $1 b$ & $\begin{array}{l}\text { Menentukan mana yang } \\
\text { merupakan himpunan } \\
\text { dan mana yang bukan } \\
\text { merupakan himpunan }\end{array}$ & 5 & 0 & 3 & 8 \\
\hline $1 \mathrm{c}$ & $\begin{array}{l}\text { Menentukan mana yang } \\
\text { merupakan himpunan } \\
\text { dan mana yang bukan } \\
\text { merupakan himpunan }\end{array}$ & & 0 응 & 1 & 8 \\
\hline $1 d$ & $\begin{array}{l}\text { Menentukan mana yang } \\
\text { merupakan himpunan } \\
\text { dan mana yang bukan } \\
\text { merupakan himpunan }\end{array}$ & 2 & 0 & 6 & 8 \\
\hline 2 & $\begin{array}{l}\text { Menentukan banyaknya } \\
\text { himpunan bagiam }\end{array}$ & 0 & 0 & 20 & 20 \\
\hline $3 a$ & $\begin{array}{l}\text { Menentukan selisih dari } \\
\text { dua himpunan }\end{array}$ & 0 & 9 & 1 & 10 \\
\hline $3 b$ & $\begin{array}{l}\text { Menentukan komplemen } \\
\text { darai dua himpnan }\end{array}$ & 0 & 9 & 7 & 16 \\
\hline $3 \mathrm{c}$ & $\begin{array}{l}\text { Menentukan gabungan } \\
\text { dari dua himpunan }\end{array}$ & 0 & 10 & 0 & 10 \\
\hline $3 d$ & $\begin{array}{l}\text { Menentukan irisan dari } \\
\text { dua himpunan }\end{array}$ & 0 & 2 & 0 & 2 \\
\hline 4 & $\begin{array}{c}\text { menyelesaikan } \\
\text { permasalahan } \\
\text { kontekstual yang } \\
\text { berkaitan dengan operasi } \\
\text { pada himpunan }\end{array}$ & 0 & 30 & 0 & 30 \\
\hline \multicolumn{2}{|r|}{ Banyaknya miskonsepsi } & 20 & 60 & 41 & 121 \\
\hline \multicolumn{2}{|c|}{$\begin{array}{c}\text { Persentase banyaknya miskonsepsi } \\
\text { yang dialami oleh siswa }\end{array}$} & $16,53 \%$ & $49,59 \%$ & $33,88 \%$ & $100 \%$ \\
\hline
\end{tabular}

Keterangan :
M1 = Miskonsepsi klasifikasional

M2 = Miskonsepsi korelasional

M3 = Miskonsepsi teoritikal

Rumus persentase banyaknya miskonsepsi yang dialami oleh siswa sebagai berikut :

Banyaknya miskonsepsi yang dialami siswa $=$

$$
\frac{\text { banyaknya miskonsepsi }}{\text { banyaknya seluruh miskonsepsi }} \times 100
$$

\section{Menentukan Subjek Penelitian}

Setelah menganalisis hasil tes pertama, peneliti memilih dua subjek penelitian dengan kriteria siswa yang mengalami miskonsepsi terbanyak dengan jenis miskonsepsi yang beragam. Peneliti menamakan subjek pertama dengan inisial SP1 dan subjek kedua dengan inisial SP2. Peneliti melakukan wawancara terhadap masing-masing subjek sehingga lebih akurat serta pemberian scaffolding terhadap masing-masing subjek penelitian berdasarkan jenis miskonsepsi yang dialami. Berikut rincian jenis miskonsepsi yang dialami oleh subjek penelitian.

Tabel 4. Rincian jenis miskonsepsi oleh subjek pada tes pertama

\begin{tabular}{|c|c|c|c|c|c|c|c|c|c|c|}
\hline Sub & \multicolumn{10}{|c|}{ Nomor Soal } \\
\hline jek & 19 & $1 \mathrm{~b}$ & 1c & 1d & 2 & $3 a$ & $3 \mathbf{b}$ & $3 c$ & 3d & 4 \\
\hline SP1 & M3 & M3 & M3 & M1 & M3 & M2 & M2 & M2 & - & M2 \\
\hline SP2 & - & M3 & M1 & M1 & M3 & M2 & M2 & M2 & - & M2 \\
\hline
\end{tabular}

Dari 10 pertanyaan yang tersedia, SP1 mengalami 9 miskonsepsi dengan masing-masing 1 miskonsepsi klasifikasional (M1) yaitu suatu pernyataan yang seharusnya merupakan himpunan tetapi SP1 menyatakan bahwa pernyataan tersebut bukan merupakan himpunan (SP11d), 4 miskonsepsi korelasional (M2) yaitu SP1 menganggap bahwa selisih dua himpunan merupakan irisan dari dua himpunan tersebut (SP13a), komplemen dari suatu himpunan merupakan himpunan yang anggotanya merupakan anggota dari semestanya tetapi bukan anggota dari himpunan lain yang diketahui (SP13b), gabungan dari dua himpunan merupakan irisan dari dua himpunan tersebut (SP13c) dan salah dalam mempresentasikan soal kedalam diagram (SP104) serta 4 miskonsepsi teoritikal (M3) yaitu SP1 benar dalam menyatakan bahwa suatu kumpulan merupakan himpunan/bukan merupakan himpunan tetapi SP1 tidak dapat memberikan alasan yang jelas (SP11a, SP11b, SP11c) dan SP1 menganggap bahwa banyaknya himpunan bagian dari suatu himpunan merupakan banyaknya anggota penyusun himpunan (banyaknya anggota himpunan dan anggota himpunan yang sama tidak dihitung satu)(SP102). SP1 tidak mengalami miskonsepsi dalam menjawab soal berkaitan dengan irisan dua himpunan (SP13c) karena sudah faham dan jelas cara menentukannya.

Dari 10 pertanyaan yang tersedia, SP2 mengalami 8 miskonsepsi dengan masing-masing 2 miskonsepsi 
klasifikasional (M1) yaitu suatu pernyataan yang seharusnya merupakan himpunan tetapi SP1 menyatakan bahwa pernyataan tersebut bukan merupakan himpunan (SP21c), suatu pernyataan yang seharusnya bukan merupakan himpunan tetapi SP1 menyatakan bahwa pernyataan tersebut merupakan himpunan (SP21d), 4 miskonsepsi korelasional (M2) yaitu SP2 menganggap bahwa selisih dua himpunan merupakan gabungan dari dua himpunan (SP23a), komplemen dari suatu himpunan merupakan himpunan yang anggotanya merupakan anggota dari himpunan tersebut tetapi bukan anggota dari suatu himpunan lain yang diketahui (SP23b), gabungan dua himpunan merupakan himpunan yang anggotanya merupakan anggota dari suatu himpunan tersebut tetapi bukan anggota dari himpunan lainya dan sebaliknya (SP23c), dan SP2 menganggap bahwa $A \cup B$ merupakan $n(A)+n(B)(\mathrm{SP} 204)$, serta 2 miskonsepsi teoritikal (M3) yaitu SP2 tidak menyertakan alasan yang jelas dalam menentukan mana pernyataan yang merupakan himpunan (SP21b), SP2 menganggap bahwa banyaknya himpunan bagian dari suatu himpunan merupakan banyaknya anggota penyusun himpunan (banyaknya anggota himpunan yang sama tidak dihitung satu) (SP202). SP2 tidak mengalami miskonsepsi dalam menjawab soal berkaitan dengan irisan dua himpunan (SP23c) karena sudah faham dan jelas cara menentukannya.

Pada soal nomor 3d, dua himpunan yang digunakan adalah dua himpunan yang berpotongan, sehingga irisan untuk dua himpunan dapat diketahui. Dari jawaban subjek didapatkan hasil bahwa SP1 dan SP2 sudah faham dan menjawab dengan tepat dalam menentukan irisan dua himpunan. Sehingga, kedua subjek tidak mengalami miskonsepsi. Hal tersebut sejalan dengan penelitian yang dilakukan oleh Lestari (2017) yang berjudul "Analisis koneksi Matematika Siswa Kelas VII dalam Menyelesaikan Soal Cerita pada materi Himpunan" bahwa siswa mampu mengenali dan menjawab soal terkait irisan dua himpunan dengan tepat.

\section{Miskonsepsi Klasifikasional}

Miskonsepsi klasifikasional yang dialami oleh siswa terdapat pada soal yang meminta siswa untuk mengelompokkan, mengklasifikasikan, dan menentukan mana yang merupakan himpunan dan mana yang bukan merupakan himpunan seperti yang temuat pada soal nomor 1. Sebanyak $20(16,53 \%)$ miskonsepsi klasifikasional yang dialami oleh siswa, terdapat deskripsi rincinya, yaitu siswa menjawab bahwa suatu pernyataan yang seharusnya merupakan himpunan tetapi siswa menyatakan bahwa pernyataan tersebut bukan merupakan himpunan dan siswa menjawab bahwa suatu pernyataan yang seharusnya bukan merupakan himpunan tetapi siswa menyatakan bahwa pernyataan tersebut merupakan himpunan. Berikut merupakan kutipan miskonsepsi SP2 untuk soal nomor 1 sub soal 1c yaitu menentukan apakah kumpulan tersebut merupakan himpunan atau tidak.

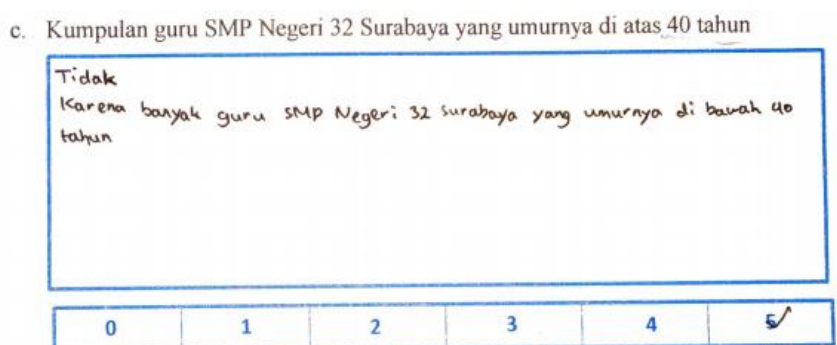

Gambar 1. Kutipan miskonsepsi SP2 untuk soal nomor 1 sub soal 1c.

Pada Gambar 1 terlihat bahwa SP2 terindikasi mengalami miskonsepsi klasifikasional, karena SP2 mengelompokkan pernyataan 1c tersebut bukan merupakan himpunan. berikut merupakan penjelasan SP2 pada saat wawancara.

P21c01 : Diketahui kumpulan guru SMPN 32 Surabaya yang umurnya di atas 40 tahun, kenapa kok kamu menjawab bukan merupakan himpunan?

SP21c01 : Karena, di SMPN 32 Surabaya, banyak guru yang umurnya di bawah 40 tahun.

P21c02 : Berarti, kalau semisal gurunya itu umurnya di atas 40 tahun semua, berarti merupakan himpunan?

$\mathrm{SP} 21 \mathrm{c} 02$ : Iya

P21c03 : Oh, jadi seperti itu maksud kamu.

Dari percakapan di atas, dapat diketahui bahwa SP2 mengalami miskonsepsi dalam mengelompokkan mana yang merupakan himpunan dan mana yang bukan merupakan himpunan. Karena ada guru yang umurnya di bawah 40 tahun, jadi SP2 menganggap bahwa kumpulan guru SMPN 32 Surabaya yang umurnya di atas 40 tahun bukanlah merupakan himpunan. Padahal jelas bahwa yang ditanyakan adalah kumpulan guru SMPN 32 Surabaya yang umurnya di atas 40 tahun, tidak menyinggung guru yang umurnya di bawah 40 tahun. Oleh karena itu, SP2 mengalami miskonsepsi klasifikasional.

\section{Miskonsepsi Korelasional}

Miskonsepsi korelasional yang dialami siswa terdapat pada soal yang berhubungan dengan operasi pada himpunan, menghubungkan antara suatu himpunan dengan himpunan yang lainnya, menyatakan hasil dari suatu operasi pada himpunan dan menyelesaikan masalah pada soal materi himpunan yang mana penyelesaian tidak hanya satu kali proses penyelesaian.

Siswa mengalami miskonsepsi korelasional pada soal nomor 3 dan 4. Sebanyak 60 (49,59\%) miskonsepsi korelasional yang dialami oleh siswa, terdapat deskripsi rincinya yaitu jika diketahui himpunan $\mathrm{A}$, himpunan $\mathrm{B}$ dan S sebagai semestanya, siswa menganggap bahwa selisih himpunan $A$ dan himpunan $B$ adalah anggota himpunan $A$ yang bukan merupakan anggota himpunan $B$ dan anggota himpunan $B$ yang bukan merupakan anggota himpunan $A$, 
selisih himpunan $A$ dan himpunan $B$ adalah gabungan himpunan $A$ dan himpunan $B$, selisih himpunan $A$ dan himpunan $B$ adalah irisan himpunan $A$ dan himpunan $B$. Siswa menganggap bahwa komplemen himpunan A merupakan himpunan yang anggotanya merupakan anggota $\mathrm{S}$ tetapi bukan anggota $A \cup B$, komplemen himpunan A merupakan himpunan yang anggotanya merupakan anggota $\mathrm{B}$ tetapi bukan anggota $\mathrm{A}$ dan anggota A tetapi bukan anggota B, komplemen himpunan A merupakan himpunan yang anggotanya merupakan anggota himpunan A yang tidak ada di B dan anggota himpunan B yang tidak ada di A, komplemen dari himpunan A merupakan anggota dari $A \cup B$, komplemen himpunan A merupakan himpunan yang anggotanya merupakan anggota B tetapi bukan anggota A, siswa menganggap bahwa gabungan dua himpunan merupakan irisan dua himpunan, gabungan himpunan A dan B merupakan himpunan yang anggotanya merupakan anggota himpunan A yang tidak ada di B dan anggota himpunan $B$ yang tidak ada di A, siswa menganggap bahwa irisan himpunan $A$ dan himpunan $B$ adalah anggota himpunan $A$ yang bukan merupakan anggota himpunan $B$ dan anggota himpunan $B$ yang bukan merupakan anggota himpunan $A$, irisan himpunan $A$ dan himpunan $B$ adalah gabungan himpunan $A$ dan himpunan $B$, anggota dari $A \cup B$ bukanlah anggota dari A ataupun anggota dari $\mathrm{B}$ dan siswa salah mempresentasikan soal menjadi gambar (diagram venn). Berikut merupakan kutipan miskonsepsi SP2 untuk soal nomor 4.

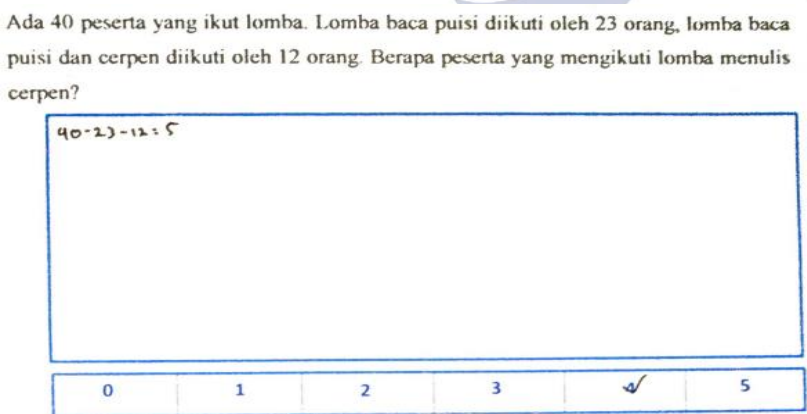

Gambar 2. Kutipan miskonsepsi SP2 untuk soal nomor 4.

Pada Gambar 2 terlihat bahwa SP2 terindikasi mengalami miskonsepsi korelasional. Dari hasil pengerjaan SP2 pada gambar 2, peneliti menduga bahwa SP2 menganggap siswa yang mengikuti lomba baca puisi dan menulis cerpen berbeda dengan siswa yang mengikuti lomba baca puisi atau siswa yang mengikuti lomba menulis cerpen. Sehingga, SP2 menjawab bahwa siswa yang mengikuti lomba menulis cerpen sebanyak 5 anak, dengan mengurangkan 40 peserta yang mengikuti lomba dengan 23 orang yang lomba baca puisi dan 12 orang yang lomba menulis cerpen. Berikut merupakan penjelasan SP2 saat wawancara.

P20401 : Nomor 4, kamu bisa menjawab 5 ini dari mana?
SP20401 : Karena ada 40 peserta yang ikut lomba dan ada 23 orang yang ikut baca puisi, dan ada 12 orang yang ikut baca puisi dan cerpen. $Y a$ itu semua dikurangi jadi $40-$ 23 - 12 sehingga hasilnya 5

P20402 : Oh berarti apakah kamu berfikiran jika 23 orang siswa yang mengikuti lomba baca puisi itu berbeda dengan 12 orang yang mengikuti lomba baca puisi dan cerpen?

SP20402 : Iya beda. Kan yang satunya kelompok yang mengikuti lomba baca puisi, yang satunya kelompok yang mengikuti lomba baca puisi dan menulis cerpen dan yang ditanyakan yang mengikuti lomba menulis cerpen

P20403 : Oh, seperti itu

Dari percakapan di atas, dapat diketahui bahwa SP2 menganggap bahwa siswa yang mengikuti lomba baca puisi dan menulis cerpen berbeda dengan siswa yang mengikuti baca puisi dan siswa yang mengikuti lomba menulis cerpen. Anggota dari $A \cup B$ berbeda dengan anggota dari $A$ dan anggota dari $B$. Oleh karena itu, dapat dikatakan bahwa SP2 mengalami miskonsepsi korelasional dalam menyelesaikan masalah kontekstual menggunakan operasi pada himpunan.

\section{Miskonsepsi Teoritikal}

Miskonsepsi teoritikal yang dialami oleh siswa didasarkan atas kesalahan dalam mempelajari fakta-fakta atau kejadian-kejadian dalam sistem yang terorganisir. Siswa salah dalam mempelajari definisi, simbol-simbol, menentukan rumus, dan kesalahan mempelajari faktafakta pada materi himpunan lainya. Sebanyak $41(33,88 \%)$ miskonsepsi teoritikal yang dialami oleh siswa, terdapat deskripsi rinci miskonsepsinya, yaitu siswa mengalami miskonsepsi saat menentukan banyaknya himpunan bagian yang disamakan dengan menentukan banyaknya anggota himpunan, siswa mengalami miskonsepsi menentukan rumus untuk menentukan banyaknya himpunan bagian dari suatu himpunan, siswa mengalami miskonsepsi saat memahami simbol-simbol matematika yang menyebabkan miskonsepsi pada konsep suatu himpunan dan siswa mengalami miskonsepsi pada definisi himpunan dan definisi suatu konsep pada himpunan. Berikut merupakan kutipan miskonsepsi SP1 untuk soal nomor 2 .

\section{Diketahui $P=\{p, a, s, t, i, b, i, s, a\}$ \\ Tentukan :}

Banyaknya himpunan bagian dari $P$

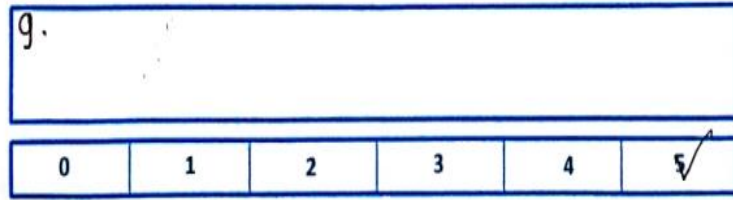

Gambar 3. Kutipan miskonsepsi SP1 untuk soal nomor 2 . 
Pada Gambar 3, terlihat bahwa SP1 terindikasi mengalami miskonsepsi teoritikal karena jawaban siswa adalah 9, peneliti menduga SP1 menganggap bahwa banyaknya himpunan bagian dari suatu himpunan merupakan jumlah anggota penyusun himpunan tersebut. Berikut ini merupakan penjelasan SP1 mengenai hasil pengerjaanya tersebut pada saat wawancara.

\section{P10201 : Sekarang coba jelaskan mengapa kamu menjawab 9?}

SP10201 : Kan yang ditanya banyaknya himpunan bagian, saya menghitung himpunan $\mathrm{P}$ kan memiliki anggota yaitu p, a, s, t, i, b, i, s, a kalau saya hitung ada 9 huruf

P10202 : Oh seperti itu

SP10202 : Iya

Dari percakapan di atas, dapat dilihat bahwa SP1 memiliki pemahaman bahwa banyaknya himpunan bagian dari suatu himpunan adalah banyaknya angka yang menyusun kata "PASTIBISA". Hal tersebut mengakibatkan SP1 mengalami miskonsepsi teoritikal.

Scaffolding Berdasarkan Jenis Miskonsepsi MasingMasing Subjek dalam Menyelesaikan Soal Tes Pertama.

Berdasarkan mikonsepsi yang dialami oleh kedua subjek dalam menyelesaikan soal tes pertama dan berdasarkan hasil wawanca yang dilakukan oleh peneliti pada masing-masing subjek, peneliti memberikan scaffolding kepada kedua subjek secara one to one. Scaffolding yang peneliti berikan pada setiap jenis miskonsepsi berupa dua level dari tiga level scaffolding yang dikemukakan oleh Anghileri (2006), sebagai berikut:

1. Level 2, explaining, reviewing and restructuring

2. Level 3, developing conceptual thinking

Kedua level scaffolding di atas merupakan acuan dalam pemberian scaffolding pada setiap jenis miskonsepsi siswa dalam menyelesaikan soal materi himpunan. Akan tetapi, pengembangannya disesuaikan dengan respon setiap subjek dan konsepnya.

\section{Pemberian Scaffolding Untuk Miskonsepsi Klasifikasional}

Pemberian scaffolding untuk miskonsepsi klasifikasional, rincian scaffoldingnya adalah meminta siswa untuk lebih teliti lagi membaca soal terkait himpunan (reviewing), memeriksa jawaban siswa dengan melihat siswa mengerjakan, bertanya dan mengambil hasil jawaban siswa (looking, touching and verbalising), siswa diminta untuk menjelaskan mengapa suatu kumpulan merupakan himpunan dan apa pengertian himpunan (prompting and probing), tanya jawab tentang apa yang sudah dikerjakan siswa mengenai himpunan (interpreting students actions and talk), membuat contoh serupa tentang kumpulan yang merupakan himpunan dan non himpunan (parallel modelling), meminta siswa menjelaskan dan membenarkan jawabannya terkait yang sudah dikerjakan (student explaining and justifying), memberikan pertanyaan mengenai pernyataan yang lebih dekat dengan siswa yang merupakan himpunan (identify meaningful context), menguraikan soal menjadi lebih sederhana (simplifying the problem), mengamati dan melakukan tanya jawab setelah membangun ulang pemahaman (re-phrasing student's talk), dan negosiasi makna dari himpunan dan nonhimpunan (negotiating meanings). Serta developing conceptual thinking yang terdiri dari developing representational tools dan making connection Scaffolding yang peneliti berikan berupa mengarahkan siswa untuk menghubungkan apa yang ditanyakan pada soal dengan hasil yang telah didapatkan.

Tabel 5. Kode scaffolding yang diberikan

\begin{tabular}{|c|c|}
\hline kode & $\begin{array}{c}\text { Keterangan } \\
\text { Explaining }\end{array}$ \\
\hline $\mathrm{L} 2 \mathrm{Aa}$ & $\begin{array}{r}\text { Looking, touching and verbalising } \\
\text { (reviewing) }\end{array}$ \\
\hline $\mathrm{L} 2 \mathrm{Ba}$ & Prompting and probing (reviewing) \\
\hline $\mathrm{L} 2 \mathrm{Bb}$ & $\begin{array}{c}\text { Interpreting students actions and talk } \\
\text { (reviewing) }\end{array}$ \\
\hline $\mathrm{L} 2 \mathrm{Bc}$ & Parallel modelling (reviewing) \\
\hline $\mathrm{L} 2 \mathrm{Bd}$ & $\begin{array}{c}\text { Student explaining and justifying } \\
\text { (reviewing) }\end{array}$ \\
\hline $\mathrm{L} 2 \mathrm{Be}$ & Identify meaningful context (restructuring) \\
\hline $\mathrm{L} 2 \mathrm{Ca}$ & Simplifying the problem (restructuring) \\
\hline $\mathrm{L} 2 \mathrm{Cb}$ & re-pharasing studdent s talk (restructuring) \\
\hline $\mathrm{L} 2 \mathrm{Cc}$ & negotiating meaning (restructuring) \\
\hline $\mathrm{L} 2 \mathrm{Cd}$ & $\begin{array}{c}\text { developing representational tools } \\
\text { (developing conceptual thinking) }\end{array}$ \\
\hline $\mathrm{L} 3 \mathrm{Aa}$ & making connection Scaffolding (developing \\
& conceptual thinking) \\
\hline $\mathrm{L} 3 \mathrm{Bb}$ & Scaftolding \\
\hline
\end{tabular}

Pemberian Scaffolding untuk Miskonsepsi Korelasional

Pemberian scaffolding untuk miskonsepsi korelasional, rincian scaffoldingnya adalah meminta siswa untuk lebih teliti lagi membaca soal terkait himpunan (reviewing), memeriksa jawaban siswa dengan melihat siswa mengerjakan, bertanya dan mengambil hasil jawaban siswa (looking, touching and verbalising), siswa diminta untuk menjelaskan tentang operasi pada himpunan (prompting and probing), tanya jawab masalah tentang apa yang sudah dikerjakan siswa mengenai operasi pada himpunan (interpreting students actions and talk), membuat contoh serupa tentang soal yang berkaitan dengan operasi pada himpunan (parallel modelling), meminta siswa menjelaskan dan membenarkan jawabannya terkait yang sudah dikerjakan (student explaining and justifying), memberikan pertanyaan mengenai pernyataan yang berhubungan operasi pada himpunan dengan menggunakan konteks yang dekat dengan siswa (identify meaningful context), menguraikan soal menjadi lebih sederhana (simplifying the problem), mengamati dan melakukan tanya jawab setelah membangun ulang pemahaman (re-phrasing student's talk), dan negosiasi makna terkait operasi pada himpunan 
(negotiating meanings). Serta developing conceptual thinking yang terdiri dari developing representational tools dan making connection Scaffolding yang peneliti berikan berupa mengarahkan siswa untuk menghubungkan apa yang ditanyakan pada soal dengan hasil yang telah didapatkan.

\section{Pemberian Scaffolding Untuk Miskonsepsi Teoritikal}

Pemberian scaffolding untuk miskonsepsi teoritikal, rincian scaffoldingnya adalah meminta siswa untuk lebih teliti lagi membaca soal terkait himpunan (reviewing), memeriksa jawaban siswa dengan melihat siswa mengerjakan, bertanya dan mengambil hasil jawaban siswa (looking, touching and verbalising), siswa diminta untuk menjelaskan mengenai teori-teori tentang himpunan, rumus-rumus menentukan himpunan bagian, simbol pada himpunan dan simbol matematika (prompting and probing), tanya jawab tentang apa yang sudah dikerjakan siswa mengenai himpunan (interpreting students actions and talk), membuat contoh serupa tentang kumpulan yang merupakan himpunan dan non himpunan (parallel modelling), meminta siswa menjelaskan dan membenarkan jawabannya terkait yang sudah dikerjakan (student explaining and justifying), memberikan pertanyaan mengenai pernyataan yang yang termasuk himpunan yang berhubungan dengan siswa (identify meaningful context), menguraikan soal menjadi lebih sederhana (simplifying the problem), mengamati dan melakukan tanya jawab setelah membangun ulang pemahaman (re-phrasing student's talk), dan negosiasi makna dari simbol-simbol matematis (negotiating meanings). Serta developing conceptual thinking yang terdiri dari developing representational tools dan making connection Scaffolding yang peneliti berikan berupa mengarahkan siswa untuk menghubungkan apa yang ditanyakan pada soal dengan hasil yang telah didapatkan.

\section{Tes Kedua}

Setelah peneliti memberikan scaffolding terhadap masing-masing subjek sesuai dengan jenis miskonsepsi yang dialaminya, kemudian subjek mengerjakan soal tes kedua untuk mengetahui miskonsepsi siswa dalam menyelesaikan soal materi himpunan setelah diberikan perlakuan scaffolding untuk bahan pendeskripsian tentang dampak pemberian scaffolding terhadap miskonsepsi siswa dalam menyelesaikan soal materi himpunan.

Rincian jenis miskonsepsi oleh subjek pada tes kedua terangkum dalam Tabel 6 berikut.

Tabel 6. Rincian jenis miskonsepsi oleh subjek pada tes kedua

\begin{tabular}{|c|c|c|c|c|c|c|c|c|c|c|}
\hline Sub & \multicolumn{10}{|c|}{ Nomor soal } \\
\cline { 2 - 11 } jek & 1a & 1b & 1c & 1d & $\mathbf{2}$ & 3a & 3b & 3c & 3d & 4 \\
\hline SP1 & - & - & - & - & M3 & - & - & - & - & - \\
\hline SP2 & - & - & - & - & - & - & - & - & - & M2 \\
\hline
\end{tabular}

Dari pertanyaan yang telah dikerjakan, SP1 mengalami 1 miskonsepsi teoritikal (M3) yaitu menganggap bahwa himpunan bagian sama dengan anggota himpunan. Perbedaan dengan jawaban SP1 pada tes pertama adalah menganggap bahwa banyaknya himpunan bagian merupakan banyaknya anggota himpunan dimana anggota himpunan yang sama dihitung semua. SP2 mengalami 1 miskonsepsi korelasional (M3) ketika menyelesaikan masalah kontekstual yang berkaitan dengan operasi pada himpunan. SP2 menjawab bahwa peserta yang mengikuti lomba menulis cerpen adalah peserta yang mengikuti lomba menulis cerpen saja. Padahal pertanyaannya tidak ada kata "saja" atau sinonimnya. SP2 menganggap bahwa siswa yang mengikuti lomba menulis cerpen sekaligus baca puisi bukan merupakan siswa yang mengikuti lomba menulis cerpen.

Berikut merupakan tabel miskonsepsi SP1 pada tes pertama dan tes kedua.

Tabel 7. Miskonsepsi SP1 pada tes pertama dan tes kedua.

\begin{tabular}{|c|c|c|c|c|c|c|c|c|c|c|}
\hline \multirow{2}{*}{$\begin{array}{c}\text { Hasil } \\
\text { tes }\end{array}$} & \multicolumn{10}{|c|}{ Nomor soal } \\
\cline { 2 - 11 } & $\mathbf{1 a}$ & $\mathbf{1 b}$ & $\mathbf{1 c}$ & $\mathbf{1 d}$ & $\mathbf{2}$ & $\mathbf{3 a}$ & $\mathbf{3 b}$ & $\mathbf{3 c}$ & $\mathbf{3 d}$ & $\mathbf{4}$ \\
\hline pertama & $\mathrm{M} 3$ & $\mathrm{M} 3$ & $\mathrm{M} 3$ & $\mathrm{M} 1$ & $\mathrm{M} 3$ & $\mathrm{M} 2$ & $\mathrm{M} 2$ & $\mathrm{M} 2$ & - & $\mathrm{M} 2$ \\
\hline Kedua & - & - & - & - & $\mathrm{M} 3$ & - & - & - & - & - \\
\hline
\end{tabular}

Berdasarkan Tabel 7, terlihat bahwa miskonsepsi SP1 berkurang setelah diberikan perlakuan scaffolding. Hal tersebut sesuai dengan penelitian sebelumnya tentang miskonsepsi ataupun tentang scaffolding diantaranya penelitian yang dilakukan oleh Suryani, dkk (2018), yang berjudul "Analisis Miskonsepsi dan pemberian Scaffolding Siswa Kelas V Dalam Menyelesaikan Soal Matematika Materi pembagian Pecahan di Sekolah Dasar Negeri Angsoka" disimpulkan bahwa scaffolding dapat mengurangi miskonsepsi siswa dalam menyelesaikan soal matematika materi pembagian pecahan. Kemudian penelitian yang dilakukan oleh Jamil (2018), yang berjudul "Pembelajaran berbasis Scaffolding Untuk mengurangi Miskonsepsi Aljabar Mahasiswa" disimpulkan bahwa pembelajaran berbasis scaffolding dapat mengurangi miskonsepsi aljabar mahasiswa.

Berikut merupakan tabel miskonsepsi SP2 pada tes pertama dan tes kedua.

Tabel 8. Miskonsepsi SP2 pada tes pertama dan tes kedua.

\begin{tabular}{|c|c|c|c|c|c|c|c|c|c|c|}
\hline \multirow{2}{*}{$\begin{array}{c}\text { Hasil } \\
\text { tes }\end{array}$} & \multicolumn{10}{|c|}{ Nomor soal } \\
\cline { 2 - 12 } & $\mathbf{1 a}$ & $\mathbf{1 b}$ & $\mathbf{1 c}$ & $\mathbf{1 d}$ & $\mathbf{2}$ & $\mathbf{3 a}$ & $\mathbf{3 b}$ & $\mathbf{3 c}$ & $\mathbf{3 d}$ & $\mathbf{4}$ \\
\hline Pertama & - & M3 & M1 & M1 & M3 & M2 & M2 & M2 & - & M2 \\
\hline Kedua & - & - & - & - & - & - & - & - & - & M2 \\
\hline
\end{tabular}

Berdasarkan Tabel 8, terlihat bahwa miskonsepsi SP2 berkurang setelah diberikan perlakuan scaffolding. Hal tersebut sesuai dengan penelitian sebelumnya tentang miskonsepsi ataupun tentang scaffolding diantaranya penelitian yang dilakukan oleh Suryani, dkk (2018), yang berjudul "Analisis Miskonsepsi dan pemberian Scaffolding Siswa Kelas V Dalam Menyelesaikan Soal Matematika Materi pembagian Pecahan di Sekolah Dasar Negeri 
Angsoka" disimpulkan bahwa scaffolding dapat mengurangi miskonsepsi siswa dalam menyelesaikan soal matematika materi pembagian pecahan. Kemudian penelitian yang dilakukan oleh Jamil (2018), yang berjudul "Pembelajaran berbasis Scaffolding Untuk mengurangi Miskonsepsi Aljabar Mahasiswa" disimpulkan bahwa pembelajaran berbasis scaffolding dapat mengurangi miskonsepsi aljabar mahasiswa.

Dari Tabel 7 dan 8, dapat dikatakan bahwa scaffolding merupakan salah satu alternatif untuk merespon miskonsepsi dan mengurangi miskonsepsi yang dialami oleh siswa dalam menyelesaikan soal materi himpunan.

\section{PENUTUP}

\section{Simpulan}

Berdasarkan penelitian yang dilakukan oleh peneliti di SMP Negeri 32 Surabaya, sebanyak 35 siswa yang mengikuti tes pertama mengalami miskonsepsi dengan jenis dan banyaknya miskonsepsi yang berbeda-beda untuk setiap siswa. Deskripsi rinci miskonsepsi klasifikasional yang dialami siswa yaitu suatu kumpulan yang seharusnya merupakan himpunan tetapi siswa menyatakan bahwa kumpulan tersebut bukan merupakan himpunan dan siswa menjawab bahwa suatu kumpulan yang seharusnya bukan merupakan himpunan tetapi siswa menyatakan bahwa kumpulan tersebut merupakan himpunan.

Miskonsepsi korelasional yang dialami siswa terdapat pada soal yang berhubungan dengan operasi pada himpunan, menghubungkan antara suatu himpunan dengan himpunan yang lainnya, menyatakan hasil dari suatu operasi pada himpunan dan menyelesaikan masalah pada soal materi himpunan yang mana penyelesaian tidak hanya satu kali proses penyelesaian.

Miskonsepsi teoritikal yang dialami oleh siswa, terdapat deskripsi rinci miskonsepsinya, yaitu siswa mengalami miskonsepsi saat menentukan banyaknya himpunan bagian yang disamakan dengan menentukan banyaknya anggota himpunan, menentukan rumus untuk menghitung banyaknya himpunan bagian dari suatu himpunan, memahami simbol-simbol matematika yang menyebabkan miskonsepsi pada konsep suatu himpunan, dan siswa mengalami miskonsepsi dalm memahami definisi himpunan dan definisi suatu konsep pada himpunan.

Bentuk scaffolding yang peneliti berikan terhadap tiap jenis miskonsepsi berupa scaffolding yang dikemukakan oleh Anghileri (2006) yaitu scaffolding Level 2: exsplaining reviewing, and restructuring. Untuk reviewing sendiri terdiri atas (a) looking, touching and verbalising (b) Pompting and probing (c) interpreting student's actions and talk, (d) paraldell modelling dan (e) students explaining and justifying. Untuk restructuring terdiri atas (a) identify meaningfull context (b) simplifying the problem (c) re-pharasing studdent's talk (d) negotiating meaning dan scaffolding level 3: developing conceptual thinking yang terdiri dari developing representational tools dan making connection.

Setelah pemberian scaffolding, siswa sudah tidak mengalami miskonsepsi klasifikasional dari yang awalnya mengalami 2 miskonsepsi klasifikasional sebelum diberi perlakuan scaffolding. Siswa mengalami 1 miskonsepsi korelasional (M3), ketika menyelesaikan masalah kontekstual yang berkaitan dengan operasi pada himpunan dari yang sebelumnya mengalami 8 miskonsepsi korelasional sebelum diberikan perlakuan scaffolding. Siswa mengalami 1 miskonsepsi teoritikal (M3) yakni menganggap bahwa himpunan bagian sama dengan anggota himpunan dari yang awalnya mengalami 6 miskonsepsi teoritikal sebelum diberi perlakuan scaffolding. Berdasarkan hasil penelitian tersebut, dapat dikatakan bahwa scaffolding dapat mengurangi miskonsepsi siswa dalam menyelesaikan soal materi himpunan.

Saran

Bagi guru, sebaiknya merancang pembelajaran sedemikian hingga siswa tidak mengalami miskonsepsi dan menyiapkan scaffolding untuk siswa yang mengalami miskonsepsi. Guru lebih menekankan pada pemhaman konsep siswanya terlebih dahulu. Selain itu, sebaiknya siswa lebih banyak dilatih mengenai konsep pemahaman suatu materi, dan tidak hanya menghafal tanpa tahu konsep yang dihapal.

Bagi peneliti yang ingin melaksanakan penelitian yang sejenis sebaiknya menganalisis hasil pemberian scaffolding terhadap miskonsepsi siswa pada materi himpunan atau materi yang lain dengan subjek yang lebih banyak atau semua siswa yang mengalami miskonsepsi, sebaiknya menggunakan variasi soal lain terkait irisan dua himpunan sehingga didapatkan miskonsepsi siswa dalam menentukan irisan dua himpunan, sebaiknya melakukan penelitian lebih lanjut mengenai miskonsepsi siswa dengan jenis miskonsepsi yang berbeda dan scaffolding yang berbeda dan sebaiknya menggunakan referensi untuk penelitian yang sejenis.

\section{DAFTAR PUSTAKA}

Abraham, M. R., Grzybowski, E. B., Renner, J. W., \& Marek, E. A. 1992. "Understandings and Misunderstandings of Eighth Graders of Five Chemistry Concepts Found in Textbooks". Journal of Research in Science Teaching, 29(2), 105-120.

Anghileri, J. 2006. "Scaffolding practices that enhance mathematics learning". Journal of Mathematics Teacher Education., 9(1), 33-52.

Jurnal diperoleh dari https://doi.org/10.1007/s10857006-9005-9 
Ashlock. 2008. Misconception and Error Patterns.(online),

(http://ptgmedia.pearsoncmg.com/images/97801350 09109/downloads/Ashlock_Ch1_Misconceptionsand ErrorPatterns.pdf, diakses tanggal 5 Januari 2020).

Damayanti, N. W. 2016. "Praktik Pemberian Scaffolding Oleh Mahasiswa Pendidikan Matematika Pada Mata Kuliah Strategi Belajar Mengajar ( Sbm ) Matematika”. Jurnal Ilmiah.Fakultas Keguruan Dan Ilmu Pendidikan,. 18(1), 87-97.

Salirawati, Das. 2011. Pengembangan Instrumen Pendeteksi Miskonsepsi Kimia Identifikasi Miskonsepsi Siswa pada Peserta Didik SMA. Disertasi. Yogyakarta : PPs Universitas neegeri Yogyakarta.

Hasan, S., Bagayoko, D., \& Kelley, E. L. 1999. "Misconceptions and the Certainty of Response Index ( CRI )". Journal from Departemen of Science of Mathemtic Education, Southern University and A\&M College, Baton Rouge, LA 70813, USA.

jurnal diperoleh dari : https://doi.org/10.1088/0031$\underline{9120 / 34 / 5 / 304}$

Herutomo, R. A., \& Saputro, T. E. mulyono. 2014. "Analisis Kesalahan Dan Miskonsepsi Siswa Kelas Viii Pada Materi Aljabar”. Jurnal Edusentris. 1(2), 134.

Jamil, Anis Farida. 2018. "Pembelajaran berbasis Scaffolding Untuk Mengurangi Miskonsepsi Aljabar Mahasiswa". Jurnal Universitas muhammadiyah Malang.

Lestari, D. 2017. "Analisis koneksi Matematika Siswa Kelas VII dalam Menyelesaikan Soal Cerita pada materi Himpunan”. Eprints : Jurnal Universeitas Muhammadiyah Surakarta.

Masriyah, dkk. 2007. Evaluasi Pembelajaran Matematika. Jakarta : Universitas terbuka

Nurtasari, A. R., Jamiah, Y., \& Suratman, D. 2012. "Miskonsepsi Siswa Pada Materi Himpunan di Kelas VII SMP Santa Monika Kubu Raya". Jurnal FKIP Untan, Pontianak, 66, 37-39.

Ormrod, Jeanne Ellis. 2009. Psikologi Pendidikan Membantu Siswa Tumbuh dan Berkembang. Jilid 1. Jakarta: Erlangga.

Suparno, P. 2013. Miskonsepsi dan Perubahan Konsep dalam Pendidikan Fisika. Jakarta: PT. Gasindo).

Suryani, Sri.,Wuryastuti S, Mashudi, E A. (2018). “Analisis Miskonsepsi Dan Pemberian Scaffolding Siswa Kelas V Dalam menyelesaikan Soal Matematika Materi Pembagian pecahan di Sekolah Dasar Negeri Angsoka". Jurnal PGSD Universitas Pendidikan Indonesia.

Sutiarso, S. 2009. Scaffolding dalam Pembelajaran Matematika. Yogyakarta:. Pendidikan Dan Penerapan MIPA, Universitas Negeri Yogyakarta. 527-530.

Tayubi, Y. R. 2005. "Identifikasi miskonsepsi pada konsepkonsep fisika menggunakan Certainty of Response Index (CRI)". Jurnal universitas pendidikan Indonesia, 3(24), 4-9.

Ummah, Azizah Qurrotul. 2016. Pemberian Scaffolding Berdasarkan Kesalahan Siswa dalam Menyelesaikan Soal yang Berkaitan Dengan Persegi dan Persegipanjang Ditinjau Dari Kemampuan Matematika. Skripsi tidak diterbitkan. Surabaya :PPs Universitas Negeri Surabaya. 